\title{
Viajantes de saias: escritoras e ideias antiescravistas numa perspectiva transnacional (Brasil, século XIX)
}

Travelers in skirts: women writers and anti-slavery ideas through a transnational perspective (Brazil, $19^{\text {th }}$ century) ${ }^{1}$

Ludmila de Souza Maia*

\section{RESUmo}

As escritoras Adèle Toussaint-Samson e Nísia Floresta expuseram, em seus livros, suas viagens em diferentes partes do Atlântico. Elas refletiram sobre o sentido de serem autoras e viajantes. As memórias de Toussaint-Samson sobre sua experiência no Brasil e o tratado de Floresta sobre a educação das mulheres são fontes relevantes para compreender suas visões de mundo bem como a circulação transnacional de ideias. Seus escritos são centrais para este artigo, que pretende investigar como suas experiências de viajantes e seus relatos sobre os papéis de gênero e a escravidão foram moldados por meio de comparações feitas entre diferentes sociedades. Elas se deslocaram do Brasil para outras partes do globo, com o intuito de construir seus argumentos sobre a sociedade brasileira. Observando o Brasil, elas se envolveram em discussões que percorreram lugares diversos.

Palavras-chave: escritoras; Brasil; século XIX.

\section{Abstract}

The writers Adèle Toussaint-Samson and Nísia Floresta exposed in their literary works their lives of movement in many parts of the Atlantic. They also reflected about their social condition as female authors and travelers. ToussaintSamson's memoirs of her experience in Brazil and Floresta's treatise on women's education are rich sources for comprehending their worldviews and the transnational circulation of ideas. Their writings are at the core of this article in which I investigate how their experiences as well as their accounts of gender roles and slavery were shaped by comparisons among different societies. They show how they move from Brazil to other parts of the globe to constitute their arguments about Brazilian society. Through their experiences, they articulate a global history. As they viewed Brazil, they engaged in discussions that crossed oceans and circulated in different continents.

Keywords: female writers; Brazil; $19^{\text {th }}$ century.

* Doutoranda, Rice University, Texas, EUA.ludmilasouzamaia@gmail.com 
Enfim, a falua atraca; eis que chegamos. Os negros lançam-se à água e levantam-me em seus braços robustos para pôr-me em terra.

Toussaint-Samson, 2003, p.74

Em um belo dia em 1849, a escritora francesa Adèle Toussaint-Samson chegou ao porto do Rio de Janeiro. Ela destacou a presença de trabalhadores negros como uma de suas maiores surpresas. Naquela época, a cidade do Rio de Janeiro era praticamente uma cidade africana (Karasch, 1987). Viajantes, pintores e cientistas de diferentes partes do mundo percebiam a enorme massa de escravos e pessoas negras nas ruas, no porto e nas praças do Rio. Em 1849, o Império brasileiro realizou um censo no Rio em que essa experiência foi quantificada. Mais de metade da população urbana era composta de cativos; quase $42 \%$ dos habitantes do Rio eram escravos nascidos na África (Census... 1849).

A escravidão seria um dos assuntos mais frequentes das memórias de Adèle Toussaint-Samson, publicadas na França no final dos anos 1870. Em 1849, ela viajou ao Brasil acompanhada por seu marido e pelo filho recémnascido, e trabalhou como professora de línguas durante sua estada de 12 anos (Canelas, 2007). Ao longo da vida, cruzou o Atlântico ao menos cinco vezes, nem sempre acompanhada. Grande parte do que ela escreve compara o "Novo" e o "Velho" Mundo, e a escravidão aparece como um contraste imenso entre os dois.

Em novembro do mesmo ano, a escritora brasileira Nísia Floresta ${ }^{2}$ embarcou no navio francês Ville de Paris para Le Havre, França (Duarte, 2008). Ela estava acompanhada de seus filhos em uma viagem de 3 anos de duração em busca de saúde, conhecimento e civilização. Sua experiência na Europa, especialmente seu contato com ideias abolicionistas, contribuiu para seus argumentos explícitos contrários à escravidão em um momento no qual o abolicionismo estava longe de ser uma unanimidade. Ela tinha vivido em quatro diferentes províncias no Brasil e veria diferentes países na Europa. Trabalhou como diretora de escola e tutora no Brasil e escreveu diversos textos para públicos brasileiros e europeus. Após sua volta ao Brasil em 1853, publicou um tratado sobre a educação das mulheres em que condenou a escravidão por razões morais e sustentou que ela era danosa para as famílias brasileiras. 
Essas autoras refletiram sobre sua condição como mulheres viajantes e também observaram as formas de sujeição humana presentes na sociedade brasileira, comparando-as com as nações "livres e civilizadas". Cada uma delas enfocou essas questões por razões diferentes e de formas diferentes; entretanto, elas compartilhavam experiências relativas à submissão das mulheres e ao cativeiro dos negros, especialmente das mulheres negras. Suas viagens parecem ter moldado a maneira como conceberam suas ideias: mediante uma comparação contínua entre os mundos diversificados da sociedade escravista brasileira e das sociedades norte-atlânticas "civilizadas". Os textos dessas autoras mostram o Brasil como uma parte do mundo atlântico ou até do mundo global.

\section{A CIRCULAÇÃo DE MULHERES E IDEIAS}

À primeira vista, as viagens dessas autoras parecem excepcionais, mas a circulação de pessoas pelo globo não era insignificante no século XIX. Como Toussaint-Samson e Floresta, muitos outros indivíduos tiveram uma vida de deslocamento espacial constante em meados do século XIX. ${ }^{3}$ Os marinheiros eram o caso mais notório de vidas em movimento constante. Entretanto, a história global do século XIX está repleta de correntes de trabalhadores migrantes: transporte de condenados pela justiça do Reino Unido para a Oceania, recrutamento de trabalhadores indianos para o Caribe, trabalho em regime de servidão nos Estados Unidos, comércio de escravos da África para as Américas e migração voluntária de europeus para o continente americano em busca de prosperidade. Esses exemplos incluíam homens e mulheres, embora indivíduos do sexo masculino pareçam ter constituído a maioria. Esses processos de migração em larga escala foram centrais para a história global no século XIX. Este artigo, contudo, investiga uma história importante de escala muito menor.

Escravas e trabalhadoras livres eram obrigadas a se reassentar por causa do comércio de escravos ou da precariedade da vida. Enquanto isso, outras mulheres das classes média e alta escolhiam ou sonhavam com uma vida de movimento que lhes possibilitasse ir para bem longe de sua pátria. As normas familiares impeliam a maioria das mulheres burguesas a cuidar da família e do lar. A domesticidade era um valor moral venerado e reproduzido em muitos textos literários, em práticas jurídicas e religiosas e em outras expressões culturais de várias sociedades (Anagol, 2006; Valenze, 1995). Entretanto, nem todas as mulheres burguesas foram efetivamente restringidas à esfera 
doméstica, ainda que tivessem de negociar esse ideal de reclusão e dedicação à família.

Adèle Toussaint-Samson fez anotações durante sua estada no Brasil ao longo da década de 1850 e as publicou na França em 1877. Nísia Floresta escreveu seu tratado sobre a educação das mulheres pouco tempo depois de voltar da Europa para o Brasil, em 1853. Ambas estavam preocupadas com a sociedade brasileira, mas também articularam definições mais amplas de gênero, trabalho e raça, debatendo essas questões de uma perspectiva transnacional ou até global.

Interpreto a maneira como elas usaram sua autoridade como mulheres viajantes instruídas para tratar da escravidão e da condição das mulheres brancas e negras na sociedade escravista brasileira. Em seus textos, elas criticaram a escravidão por ser imoral, ineficiente e cruel, mas também tinham uma concepção depreciativa dos escravos. Suas opiniões críticas da escravidão lhes possibilitavam reivindicar um lugar no espaço público para as mulheres burguesas e para apresentar as atividades domésticas das mulheres como um trabalho respeitável e valioso. Seus comentários sobre a escravidão surgiram de comparações com sociedades norte-atlânticas em que muitas mulheres de classe média executavam tarefas domésticas sozinhas ou com a ajuda de uma criada livre. Como essas mulheres, Floresta e Toussaint-Samson se consideravam capazes de sustentar sua família com seu trabalho remunerado e seu labor reprodutivo não remunerado como esposas e mães. Floresta se tornou o ganha-pão da família ocasionalmente antes da morte do marido e permanentemente depois dela. Toussaint-Samson contribuiu para a renda de sua família como professora e escritora de textos jornalísticos. Essas mulheres circularam pelo mundo por conta própria. Não obstante, no Brasil o seu status de mulheres livres sempre era limitado por questões morais relacionadas a gênero, raça e classe porque tinham ascendência europeia em uma sociedade de escravos.

\section{ESCRITORAS TALENTOSAS}

Floresta e Toussaint-Samson eram autoras em um ambiente de editores e escritores dominado por homens. Elas, aparentemente, sempre tiveram a intenção de publicar suas obras. Por essa razão, empregaram um discurso de autoempoderamento em seus textos. Isso criou uma imagem de profissionalismo para elas como autoras e narradoras. Utilizaram estratégias diferentes para reforçar sua autoridade, mas ambas escolheram as comparações transnacionais para mostrar seu conhecimento adquirido nas viagens. As obras de 
Toussaint-Samson e Floresta foram, consequentemente, moldadas intencionalmente por sua experiência de deslocamento, e seus juízos deviam-se em parte aos seus encontros com culturas diversas.

Em 1877, o imperador brasileiro Pedro II visitou Paris, o que deu a Adèle Toussaint-Samson a oportunidade de publicar suas notas sobre o Brasil na imprensa francesa. Depois de muitas tentativas fracassadas, dessa vez ela convenceu seu editor a publicar partes do seu trabalho no jornal Le Figaro. O periódico tinha o objetivo de agradar os leitores franceses com novidades sobre o Brasil. ${ }^{4}$ Em 1883, as memórias foram reunidas para formar um livro que foi publicado primeiro na França, e, logo depois, traduzido e lançado no Brasil. Em 1891, o livro chegou aos Estados Unidos. Seu público estava, portanto, localizado em diferentes partes do Atlântico.

No prefácio do livro, Toussaint-Samson começa agradecendo a um amigo e escritor célebre:

Ao senhor Louis Jacolliot,

Enquanto está a sonhar à beira-mar ou em sua encantadora habitação indiana, esquecido de Paris e dos parisienses, eu, meu caro amigo, penso com frequência no infatigável viajante, no apaixonado admirador da Índia, cujos relatos tiveram tanto sucesso e deleitaram-me por noites inteiras; e é para dar-lhe prova de minha profunda simpatia que lhe peço aceitar a dedicatória deste pequeno volume, que muitas vezes insistiu comigo para que terminasse. Possa ele, ao lê-lo, não se arrepender demais de seu imprudente conselho! (ibidem, p.1)

Essas palavras anunciavam ao leitor que seu trabalho fazia parte de uma longa tradição de relatos de viagem. A amizade com um grande autor e o incentivo desse autor para que ela publicasse suas notas eram, além disso, uma estratégia de empoderamento. No livro, ela menciona e cita diversas obras clássicas sobre o Brasil escritas por viajantes famosos. No entanto, também deixa claro que não aceitou as informações nesses livros ao pé da letra, mas se baseou em sua própria experiência de viagem, "mais verdadeira".

Toussaint-Samson também enfatizou seu próprio profissionalismo. Seu prefácio menciona que enfrentou obstáculos levantados por editores por causa do seu gênero, não de seu talento, e que, por fim, foi bem paga pela publicação do seu trabalho. É possível que ela estivesse procurando, desse modo, distanciar-se do rótulo de amadora, comumente aplicado a mulheres artistas naquele tempo (Simioni, 2008). 
Adèle Toussaint-Samson também utilizou suas leitoras para assumir uma posição de autoridade enquanto narradora. Por exemplo, Uma parisiense no Brasil $l^{5}$ dá conselhos para as mulheres sobre viajar sozinha: "A terceira é a viajante 'séria' ou artista, que troca palavras com todos sem se ligar a ninguém, sobe à ponte quando todo mundo desce dali, para gozar um belo nascer do sol ou um esplêndido luar" (Toussaint-Samson, 2003, p.62-63). Esse conselho a mulheres leitoras sugere um modelo de conduta moral, cortesia e austeridade baseado em sua experiência como viajante. Seu livro pertence a um gênero literário preocupado com a proximidade entre vida e narrativa e com a verossimilhança. Toussaint-Samson enfatiza a veracidade de seu depoimento, evitando o que considera relatos de viagem "fantásticos" sobre o continente americano. Na segunda metade do século XIX, a figura da viajante europeia de classe média que deixa seu lar para "erigir a civilização" e espalhar o cristianismo no além-mar era comum. Usando argumentos morais e religiosos, muitas mulheres de nações europeias trabalharam para seus impérios a fim de ganhar uma posição na esfera pública, embora no exterior. Toussaint-Samson poderia estar tentando adaptar esse exemplo atrativo de mulheres poderosas que usavam seu tempo de maneira ambiciosa e produtiva para impulsionar a sociedade rumo ao progresso. ${ }^{6}$

O mesmo tipo de exemplo feminino também inspirou Nísia Floresta e a levou a disseminar "novas" ideias sobre as mulheres para um público brasileiro: "Enquanto pelo velho e novo mundo vai ressoando o brado - emancipação da mulher - nossa débil voz se levanta, na capital do império de Santa Cruz, clamando: educai as mulheres!” (Floresta, 1989, p.2). Essas são as palavras introdutórias de Opúsculo humanitário, ${ }^{7}$ um tratado sobre educação feminina no qual a narradora revela sua nacionalidade brasileira, mas não seu gênero feminino. O trabalho de Floresta foi publicado primeiramente em 1853 como uma série de crônicas nas páginas do jornal carioca Diário do Rio de Janeiro, logo após seu retorno da Europa para o Brasil. Os leitores contemporâneos não faziam ideia de que essa série era escrita por uma mulher. ${ }^{8}$ No final de 1853, esses textos foram, igualmente, reunidos em um volume, e àquela altura Floresta revelou seu gênero, mas não seu nome verdadeiro, publicando-os, em vez disso, sob um pseudônimo. ${ }^{9}$ Agradecendo a ajuda de seu irmão, Floresta usa uma típica fórmula de modéstia ao descrever seu trabalho como "imperfeito”. Não obstante, ela também apresenta seu conhecimento como especialmente preciso em função de sua experiência como viajante e educadora. $\mathrm{O}$ encontro com a "civilização" em diferentes partes da Europa moldou seu pensamento, como ela mesma afirma no livro. 
Opúsculo humanitário é um tratado, e seus argumentos sobre a educação feminina se baseiam em comparações entre sociedades. Ela começa com a exigência de que o Brasil liberte as mulheres da ignorância e de costumes patriarcais. Sua defesa da liberdade se estende a ideias antiescravistas. A principal afirmação de seu livro é que existe uma relação profunda entre o grau de civilização de uma nação e o papel das mulheres em tal sociedade: quanto mais educado e livre for o sexo feminino, mais civilizada será a nação.

Floresta utiliza uma variedade de métodos para conferir autoridade à sua narrativa. Primeiro, ela exibe a erudição adquirida nas viagens. Por exemplo, quando a narrativa critica tutores europeus que vinham ao Brasil sem nenhuma certificação, a narradora sustenta que viveu na Europa e tem condições de afirmar que tais tutores eram profissionais desqualificados: "Vivemos algum tempo na Europa e sabemos que as pessoas ali reputadas de letras e habilitadas para o magistério têm sempre em que se empreguem com mais ou menos vantagem. A ideia de deixarem o seu país para virem instruir a nossa mocidade jamais lhes ocorreu" (Floresta, 1989, p.79). Em segundo lugar, a narrativa usa comparações entre nações e sociedades. As sociedades norte-atlânticas servem como modelos para a sociedade brasileira. Como outros textos escritos pela autora também indicam, isso é mais uma estratégia retórica do que uma crença filosófica de Floresta. Seus argumentos eurocêntricos servem para expor os leitores brasileiros a outras formas de organização social. Quando escreve para públicos europeus, seus argumentos são bastante diferentes, e ela é uma crítica ácida dos valores europeus. Em outras palavras, ela intensifica suas afirmações fazendo referência a um Outro. Por fim, a narradora também demonstra erudição ao citar autores famosos do passado e do presente. Ela critica as opiniões de Rousseau e debate a famosa obra Uncle Tom's Cabin [A cabana do Pai Tomás], de Harriet Beecher Stowe, que fora publicada pouco antes de Opúsculo humanitário. As viagens transatlânticas da autora, assim como as ideias amplamente disseminadas que usou para discutir a realidade brasileira, conferem autoridade à sua narrativa. Desse modo, Floresta aproveitou seus deslocamentos espaciais para obter credibilidade e empatia perante seu público patriarcal.

Para além das diferenças de gênero literário, ideologia e nacionalidade, Adèle Toussaint-Samson e Nísia Floresta, como mulheres viajantes e escritoras, utilizaram estratégias similares para conferir autoridade a suas narrativas. Ser mulheres burguesas em sociedades patriarcais como o Brasil a França do século XIX significa que elas se defrontaram com certas normas sociais, e as 
possibilidades e restrições relacionadas a seus movimentos contribuíram para moldar seu modo de pensar.

\section{O CATIVEIRO DE MULHERES LIVRES}

Viajantes homens do século XIX descreveram as mulheres brasileiras como submissas a seus parentes masculinos e presas ao âmbito privado da casa. Adèle Toussaint-Samson e Nísia Floresta também fizeram isso. No entanto, elas criaram um panorama mais complexo da condição das mulheres no Brasil, possivelmente pelo fato de poderem entrar nos âmbitos privados da vida brasileira que eram comumente proibidos aos homens que escreviam sobre viagens. Como mulheres, elas tinham condições de descrever a vida das mulheres brasileiras com maior profundidade e, graças às suas viagens, podiam comparar a condição das brasileiras com as de mulheres em outros lugares.

O texto de Nísia Floresta se refere com frequência aos relatos de viagem de europeus sobre o Brasil. Como eles, ela condena a "languidez indolente" do sexo feminino no país. Diferentemente deles, porém, sua narrativa culpa os costumes atrasados dos pais e mães, especialmente dos pais que recusavam qualquer desenvolvimento intelectual a suas filhas:

Nada ... temos visto fazer-se para remover os obstáculos que retardam os progressos da educação das nossas belas mulheres, a fim de que elas possam vencer as trevas que lhes obscurecem a inteligência, e conhecer as doçuras infinitas da vida intelectual, a que têm direito as mulheres de uma nação livre e civilizada. (Floresta, 1989, p.44)

Em sua opinião expressa, as mulheres brasileiras eram presas em um cárcere de ignorância. A reforma dos costumes brasileiros era necessária para que o Brasil passasse a fazer parte das nações "livres e civilizadas". O narrador anônimo de Floresta prescreve às mulheres um dever moral rigoroso e que respeite a divisão dos sexos nas esferas pública e privada. No entanto, a narrativa também sugere às mulheres estratégias cotidianas para escapar de algumas das limitações da reclusão no âmbito doméstico e para estimular seu desenvolvimento físico e mental. Ela encontra maneiras de justificar a presença feminina no âmbito público e dá exemplos de sociedades estrangeiras. $\mathrm{O}$ texto também insiste no valor social da vida doméstica.

A narrativa de Opúsculo humanitário denuncia o modo como as mulheres no Brasil eram preparadas durante toda a sua vida para ser esposas, sendo o 
casamento seu único destino. Ela salienta que o casamento nunca foi um caminho inteiramente seguro para as mulheres, dando o exemplo de uma mulher francesa que, abandonada pelo marido, morreu na pobreza em razão de sua incapacidade de se sustentar:

Educada no meio da grandeza e amada depois por esse homem, a filha de um dos primeiros cortesãos de seu tempo devia por sem dúvida crer-se segura daquele direito, desde que o desposou e lhe deu cinco filhos. Volveu o tempo... e a pobre mãe, que nunca tinha deixado de ser esposa fiel, pereceu abandonada e miseravelmente em uma pequena casa da mesma cidade... (ibidem, p.125-126)

O texto exige que a sociedade "liberte" as mulheres do casamento preparando-as para o trabalho: "Procurem, sobretudo, habituá-las ao trabalho, apresentando-o como uma virtude necessária em todos os estados da vida, qualquer que seja a opulência do indivíduo, e não digno do desdém com que o olham certas classes" (ibidem, p.113). As mulheres deveriam estar preparadas e ser capazes de enfrentar a viuvez, o abandono ou a ruína financeira.

As mulheres brasileiras também eram mantidas prisioneiras por suas vestimentas, de acordo com o livro de Floresta. Ela condena eloquentemente os espartilhos como símbolo da opressão extrema. Nesse ponto, a leitora depara com a história de uma menininha que parece ter sido uma das alunas de Nísia Floresta:

Uma menina de 6 anos frequentava como externa aquele colégio ... ela captava a simpatia de todos e inspirava profundo interesse à diretora, que, vendo-a respirar com dificuldade sempre que entrava para as classes, tinha o cuidado de afrouxar-lhe o espartilho que lhe oprimia o peito a tal ponto. (ibidem, p.106-107)

A narrativa relata como a diretora da escola tentou convencer a mãe das consequências nefastas do espartilho para a saúde da criança. A vaidade da mãe acabou por causar o fim trágico da história: a pobre criancinha morreu por causa de um espartilho apertado. É provável que Floresta tenha recorrido a um episódio de sua vida profissional para argumentar contra a escravidão da vaidade que aprisionava as mulheres nas "frivolidades da vida" e contra o comércio de meninas no mercado matrimonial. Seu texto lamenta o "abuso fatal dos padrões da moda" (ibidem, p.107) das mães. As mulheres brasileiras, afirma a narradora, tinham um longo caminho pela frente para atingir os níveis de liberdade que as mulheres das sociedades do Atlântico Norte haviam obtido. 
Adèle Toussaint-Samson também denunciou a condição "submissa" das mulheres brasileiras, que ela justapôs, em seu relato em primeira pessoa, à sua própria situação independente como trabalhadora livre e esposa autônoma. Segundo seu relato, ela conseguiu entrar no âmbito privado das famílias brasileiras e criticar o mau tratamento das mulheres dentro do lar. Em uma de suas viagens ao interior da província do Rio de Janeiro, ela conheceu uma mulher branca que era tratada "pior do que uma escrava" por seu marido, um capataz de fazenda:

Na noite anterior, eu notara uma jovem mulher branca ou, antes, amarela, de grandes olhos com olheiras, de cabelos mal penteados, que andava descalça, vestida com uma saia malfeita, uma criança pela mão e outra no colo, e supusera que bem poderia ser a mulher do administrador, que, no entanto, tinha roupa fina, um traje decente e um verniz de letras e de ciência. (Toussaint-Samson, 2003, p.142)

A diferença entre a aparência da mulher e a do marido é o primeiro sinal da relação desigual entre o casal que Toussaint-Samson observa. Ela relata uma conversa que teve com a mulher, que prontamente conta a Adèle como seu marido a humilha:

Ele me trata indignamente. Aquelas mulatas ... é que são as verdadeiras senhoras da fazenda; por elas, meu marido me cobre de ultrajes ... Quando me recuso a isso, ele me bate e suas amantes me insultam ... Meu marido me força a receber essas criaturas até em minha cama; é lá, debaixo de meus olhos, que lhes dá suas carícias. (ibidem, p.142)

A esposa afirma que é tratada pior do que as escravas amantes do marido. Horrorizada com essa afirmação, Toussaint-Samson culpa o atraso da sociedade brasileira. Ela lembra que perguntou à infeliz mulher por que suportava tal humilhação e sugeriu que ela abandonasse o marido e achasse um trabalho pago. No entanto, a mulher lamentou que não estivesse preparada para sustentar a si mesma: "Isso é bom para as francesas, disse ela enfim, que sabem ganhar seu pão; mas nós, a quem não se ensinou nada, somos obrigadas a ser como criadas dos nossos maridos" (ibidem, p.142). Em sua narrativa, Toussaint-Samson contrapõe a si mesma e sua autonomia como trabalhadora independente àquela das mulheres "livres" no Brasil. Esse tipo de descrição aproxima a condição das mulheres livres brasileiras àquela dos escravos. Ela compara a submissão de gênero pela qual passavam as mulheres brasileiras à submissão de classe e raça sofrida pelos cativos. 
O texto de Adèle Toussaint-Samson também observa o isolamento das mulheres brasileiras pelo fato de não poderem caminhar sozinhas pelas ruas do Rio de Janeiro e contrasta essa situação com a vida das mulheres parisienses como ela, que eram (supostamente) livres para ir a qualquer lugar. De acordo com ela, a vida das brasileiras se desenrolava principalmente dentro de suas próprias casas. Por isso, em muitos relatos de viagem, elas eram descritas como preguiçosas e sedentárias. Adèle revela o contexto dessa aparente inatividade:

Uma das opiniões mais geralmente aceitas sobre a brasileira é que é preguiçosa e permanece ociosa o dia inteiro. Enganam-se. A brasileira não faz nada por si mesma, mas manda fazer; põe seu amor-próprio em jamais ser vista em uma ocupação qualquer. (ibidem, p.156)

Ela destaca os amplos deveres delas de coordenar o funcionamento da casa e o serviço doméstico dos escravos. Os escravos produziam alimentos e suprimentos para serem vendidos pelos "escravos de ganho" nas ruas do Rio de Janeiro, para gerar renda para as famílias de seus donos. Essas mulheres supostamente desocupadas de fato trabalhavam e ganhavam seu próprio dinheiro ao explorar o trabalho de escravos. Seu trabalho, no entanto, era mantido longe das vistas, já que o lazer era uma norma social para as classes altas.

A ocultação de atividades geradoras de renda não é exclusiva de sociedades escravistas como o Brasil. Em Imperial Leather, Anne McClintock explora práticas similares existentes entre as mulheres da classe média britânica. Elas frequentemente tinham de assumir a dura rotina de administrar uma casa, e, conquanto eventualmente empregassem uma jovem para ajudá-las com as tarefas domésticas, muitas vezes também trabalhavam um segundo turno escondido no negócio da família, e faziam certo esforço para ocultar as evidências de seu trabalho (McClintock, 2010).

Embora Toussaint-Samson considerasse que as mulheres brasileiras eram trabalhadoras, ela destacou sua própria posição como mulher europeia que ganhava a vida como professora, uma profissão socialmente reconhecida. Ela contrapõe sua autoimagem àquela das submissas esposas brasileiras, que estavam presas ao casamento ou aos deveres familiares como única possibilidade de ganhar a vida. Ao contrário das mulheres brasileiras que nunca deixavam suas casas, a autora inclui a si mesma no seleto grupo de mulheres francesas e britânicas que apareciam nas ruas do Rio nos anos 1850. Ela conta como sofreram o preconceito dos homens brasileiros que desdenhavam de sua moralidade e as consideravam mulheres promíscuas porque elas saíam de casa 
desacompanhadas. Ao fazer isso, Adèle reafirma sua própria imagem como mulher civilizada muito à frente dos costumes locais.

\section{NísIa Floresta: A PROFISSIONALIZAÇÃo DA MATERNIDAdE E OS PREJUÍZOS DA ESCRAVIDÃO DOMÉSTICA}

Se as mulheres da alta aristocracia das nações cultas, cercadas da prestigiosa nobreza de tantos séculos, sustentada por fortunas colossais e pelos grandes feitos de muitos de seus maiores, compreenderam enfim que o trabalho é a única égide invulnerável, assim nos grandes terremotos sociais como na agressão dos vícios em todas as classes da sociedade, como podem as nossas conterrâneas, cujo orgulho não tem como base nenhuma daquelas vantagens, desprezar o trabalho e passar todo o seu tempo ocupadas de frivolidades...?

Floresta, 1989, p.120

Nesses termos, Floresta defendeu a inclusão das mulheres no mercado de trabalho. Seu argumento em favor do trabalho livre para as mulheres estava intimamente relacionado ao contexto político do império brasileiro naquele momento. Diante da pressão internacional, o comércio transatlântico de escravos foi proibido em 1850 no Brasil, e os senhores tiveram de pensar em como repor sua força de trabalho (Hall; Stolcke, s.d.). O Diário do Rio de Janeiro publicou longas matérias sobre esse problema ao longo dos anos $1850 .^{10}$ Floresta e Toussaint-Samson tomaram parte nesse debate. Os brasileiros tinham dificuldade em imaginar sua sociedade sem a escravidão. Uma das razões era que, nas palavras de Toussaint-Samson, "ninguém quer ser servo e todos querem ser senhores”. Uma variedade de textos de meados do século XIX reproduz essa concepção da elite brasileira e seu desdém pelo trabalho. Esse é o tema central de muitos romances contemporâneos, em que o lazer era retratado como rotina para as classes senhoriais (Chalhoub, 2003). O Opúsculo humanitário de Floresta apoia o trabalho livre, uma ideia importada de nações estrangeiras, como solução para o Brasil.

Nísia Floresta sugere que, se as mulheres brasileiras estavam presas em suas casas, elas deveriam tirar o melhor partido da situação e superar os limites impostos pela domesticidade. O texto defende uma educação moral e completa para o sexo feminino, sugerindo que a maternidade e o papel de esposa fossem 
considerados uma profissão mediante a racionalização das atividades femininas. Baseada nas ideias do filósofo francês François Fénelon, Floresta sustenta que a educação deveria começar no berço (Floresta, 1989, p.94), sendo realizada por mães instruídas. Em sua opinião, as mulheres brasileiras deveriam seguir o exemplo das mães europeias que eram "trabalhadoras ativas" e "instrutoras apaixonadas” de suas próprias filhas:

Uma mãe bem educada e suficientemente instruída para dirigir a educação de sua filha obterá sempre maiores vantagens, aplicando-se com terna solicitude a inspirar-lhe como emulação o sentimento da própria dignidade, que qualquer diretora não conseguiria obter de suas educandas. (ibidem, p.91)

Desse modo, ela enfatiza a importância do papel social das mães e o trabalho da educação da família como uma atividade laboral, ainda que não remunerada (Valenze, 1995, p.162).

De acordo com a autora, a racionalização das atividades domésticas permitiria ao sexo feminino se livrar de sua própria escravidão e criaria oportunidades de trabalho remunerado para as mulheres. Nísia Floresta imagina um futuro para o Brasil sem escravidão no lar. Ela descreve os lares brasileiros como lugares de desordem por causa da escravidão e da falta de método das donas de casa:

A vida se passa para grande parte delas sem outro exercício, sem outro trabalho afora o que algumas chamam, com ênfase, governo da casa, consistindo este muita vez no desgoverno, na confusão entre o nada fazer e o ordenar constantemente sem método, sem pensamento. (Floresta, 1989, p.122)

A solução para essa cena caótica são novas ideias sobre a gestão do tempo importadas de "nações cultas". A narrativa explica como as mulheres francesas e inglesas conseguiam cuidar da casa e dos filhos, bem como ajudar os esposos e pais em atividades remuneradas:

Vimos em França e em Inglaterra mães de quatro, cinco e mais filhos, amamentando ainda um, saberem dividir e utilizar tão bem o seu tempo, que os pensavam, faziam todo o serviço interno da casa, e lhes sobravam horas para ajudarem seus maridos no comércio, nas artes ou na lavoura. (ibidem, p.124)

À medida que Floresta esboça essa ideia europeia de liberdade e trabalho proveitoso para as mulheres, aumenta o contraste com a condição de atraso das mulheres no Brasil. 
Mães diligentes também impediriam a transferência de responsabilidades maternas para amas de leite escravas, babás e serviçais. Em sua opinião, as mulheres pobres deveriam entrar no mercado de trabalho e viver independentemente, e as mulheres ricas deveriam levar suas "responsabilidades femininas" tão a sério quanto um trabalho remunerado. Essa solução não seria possível em uma sociedade na qual a escravidão detinha a marcha do progresso. A racionalização do trabalho doméstico não poderia ser conquistada em meio à irracionalidade do cativeiro.

Opúsculo humanitário especificamente alerta as famílias brasileiras sobre o perigo de escravos maus introduzidos no círculo íntimo da família. Utilizando as ideias de Jean-Jacques Rousseau, Nísia defende o aleitamento materno em vez do uso "malfazejo" de amas de leite escravas. Sua narrativa deplora o fato de que "míseras africanas ... passam, muita vez, do açoite ... ao berço do inocente para oferecer seu leite...” (ibidem, p.93). As crianças brasileiras de famílias livres aprendem, dessa maneira, uma lição de ingratidão, com resultados imorais para a formação de seu caráter: "Não é raro ver ela [a menina brasileira] ... infligir o mais cruel tratamento à própria ama que a amamentou, a qual é alguma vez indiferentemente vendida ou alugada como um fardo inútil, apenas acaba de ser-lhe necessária” (ibidem, p.96).

A autora enfatiza a violência contra as escravas infligida pelas senhoras no lar e a crueldade do aluguel de amas de leite. De fato, essa era uma das formas mais comuns de aluguel de escravos nos anos 1850. Os anúncios de amas de leite "zelosas" e "carinhosas" estavam entre os mais frequentes nas páginas do Diário do Rio de Janeiro em 1853, ${ }^{11}$ por exemplo. Naquele tempo, todas as atividades executadas por um corpo escravizado eram consideradas trabalho e podiam, em consequência, ser transformadas em mercadoria. Em contraposição àquela norma social brasileira, Nísia condena o comércio imoral do "amor materno" e das funções dos corpos femininos. Ao denunciar o dilema das amas de leite escravas (que tinham que deixar seus próprios bebês malnutridos), Opúsculo humanitário recorre a discursos antiescravistas do mundo atlântico nos quais a irmandade feminina é reclamada como uma forma que as mulheres encontraram de combater a escravidão (Cowling, 2011). $\mathrm{Na}$ opinião de Floresta, a exploração das mulheres escravizadas desvaloriza o trabalho das mulheres livres. Portanto, a liberdade das senhoras burguesas depende da liberdade das escravas.

Nísia estava em Paris quando, pouco antes da publicação de Opúsculo humanitário, a primeira tradução francesa de A cabana do Pai Tomás, de Harriet Beecher Stowe, foi lançada em 1852. Esse livro rapidamente se tornou 
o ícone dos movimentos antiescravistas ao redor do mundo, especialmente entre mulheres abolicionistas. Floresta fez frequentemente citações de $A$ cabana do Pai Tomás, e Opúsculo humanitário usa, em grande parte, a mesma retórica antiescravista. Considerado o primeiro best-seller do século XIX, o livro de Stowe foi rapidamente disseminado pelo mundo. Em 1853, a tradução portuguesa de Uncle Tom's Cabin foi publicada no Brasil (Lúcio, 2002). É possível que alguns brasileiros tenham lido versões francesas ou inglesas anteriores. Em geral, porém, o tratado de Nísia Floresta resumiu e divulgou os mais recentes debates abolicionistas de outras partes do Atlântico para os leitores no Brasil. Floresta estava ciente de seu conhecimento atualizado e suas conexões mais amplas com outras culturas literárias.

A obra de Nísia Floresta criticava a escravidão como um sinal de atraso e também convocava as mulheres brasileiras a ganhar um papel social público por meio do trabalho remunerado ou do reconhecimento das atividades femininas como trabalho valioso, mesmo que não remunerado. Para Floresta, a escravidão seria desnecessária se o trabalho fosse considerado moralmente valioso e o trabalho feminino fosse estimulado. O empoderamento das mulheres tornaria a escravidão desnecessária. As mulheres instruídas e profissionais ficariam livres da ignorância e seriam libertas do uso irracional do trabalho escravo, que era o símbolo do atraso. As mulheres poderiam mudar a sociedade mediante a utilização de trabalho livre, e seus filhos poderiam mudar o rumo da nação.

\section{AdÈle Toussaint-SAMSON: O EXOTISMO DE UMA SOCIEDADE ESCRAVISTA E A EXPLORAÇÃO DE GÊNERO DAS ESCRAVAS}

Logo o navio entra no canal, tendo à direita a Fortaleza de Santa Cruz e, à esquerda, o Forte Laje ... Durante esse tempo, chegam de todos os lados diferentes embarcações, as maiores das quais, chamadas faluas, vêm buscar passageiros, com uma parte de suas coisas. Essas faluas, uma espécie de grandes barcas com uma altíssima vela latina, são tripuladas geralmente por cinco negros robustos; o patrão mantém-se no leme, enquanto os outros quatro remam lentamente, em cadência, erguendo-se de seu banco a cada remada e voltando a sentar-se para levantar-se de novo. Essa foi uma de minhas primeiras surpresas...

Toussaint-Samson, 2003, p.71-72 
Recordando-se de sua chegada ao Rio de Janeiro, Adèle lembra quão inesperada foi para ela a presença de trabalhadores negros escravizados no porto da cidade. Escrevendo principalmente para não brasileiros, ela é cuidadosa ao detalhar as diferenças físicas desses estranhos habitantes. Remadores negros levam os passageiros do navio para terra em pequenos barcos, e ela está ciente de que seus serviços permitem a ela desfrutar da paisagem do Rio: "Enquanto eles remam para conduzir-nos a terra, deem uma olhada comigo naquela esplêndida baía, orlada de todos os lados por montanhas cobertas da mais luxuriante vegetação" (ibidem, p.73). Muitos outros viajantes também escreveram sobre suas impressões ao chegarem pela primeira vez ao Rio e sobre a beleza da paisagem. Adèle revive sua chegada, no entanto, para ressaltar a tensão entre a natureza magnífica do Brasil e seus aspectos "incivilizados”, materializados nos corpos escravizados. Como francesa, ToussaintSamson destaca o trabalho dos negros, sem vê-lo como algo natural, como faz Floresta. ${ }^{12}$

Adèle Toussaint-Samson, na verdade, sempre enfatiza a presença dos escravos, enquanto os escritores brasileiros tendiam a considerar seu trabalho como invisível. O público europeu de Adèle estava, é claro, interessado em informações "exóticas" sobre o Brasil. Por exemplo, Adèle descreve a natureza e as pessoas em sua excursão para o Corcovado, destacando a presença de escravos que transportavam provisões e tomavam conta das crianças, permitindo aos indivíduos livres desfrutar de seu tempo de lazer:

Nossa pequena caravana compunha-se de dezesseis pessoas sem contar os negros que nos acompanhavam, carregando na cabeça grandes cestos contendo as provisões de boca. Quanto às negras, estavam encarregadas das crianças, que participam de todas as festas e são levadas ao teatro, a tal ponto se tem confiança nos escravos para as vigiar. (Toussaint-Samson, 2003, p.87)

Ela revela seu desconforto com a população negra do Rio. Suas descrições também servem para saciar a curiosidade de leitores europeus que não estavam familiarizados com os detalhes da sociedade escravista brasileira.

Em vários momentos, Adèle Toussaint-Samson descreve o aspecto sensual dos corpos escravizados e, especialmente, como sua suposta hipersexualidade era explorada tanto pelos senhores quanto pelos escravos. Aqui ela sintetiza discursos raciais que supunham que os corpos das pessoas negras fossem hipersexualizados. Por exemplo, ao descrever as ruas do Rio, escravas do grupo étnico Mina chamam sua atenção: 
ornadas de belos enfeites; uma fina blusa guarnecida de renda, mal esconde seu colo, ... elas têm os pés nus numa espécie de chinelas com saltos altos, chamadas tamancas, onde deve entrar apenas a ponta do pé; seu pescoço e seus braços estão carregados de colares de ouro, de fileiras de coral e de todo tipo de fragmentos de marfim e de dentes, uma espécie de manitus, que, segundo elas, devem conjurar a má sorte... (ibidem, p.80)

Ela retrata essas mulheres bem-vestidas e exuberantes de maneira positiva, embora sua descrição encubra uma característica menos positiva. Adèle acusa essas escravas de lascívia e de causar a violência apaixonada e ruína financeira dos homens: "Nada mais devasso que essas negras Minas: são elas que depravam e envenenam a juventude do Rio de Janeiro; não é raro ver estrangeiros, principalmente ingleses, sustentá-las e fazer loucuras por elas" (ibidem, p.83-84).

Toussaint-Samson acreditava, além disso, que a sexualidade das escravas as levava à prostituição. Ela conta como suas escravas tinham uma dupla jornada, primeiro prestando serviços domésticos para seus senhores, depois trabalhando como prostitutas à noite para ganhar dinheiro para si:

Quando essas criaturas são desejadas, não se precisa mais que lhes fazer um sinal, e elas o seguem. Algumas tive em minha casa que, terminado seu serviço, desapareciam à noite para entregar-se a esse belo comércio... (ibidem, p.84)

Quando ela repreendeu suas escravas por escapar à noite, elas protestaram. Elas viam sua proibição como excessiva: "Nossas patroas brasileiras não são como a senhora, e nos deixam algumas horas para isso toda noite" (ibidem, p.84). Aqui vemos um indício de como práticas costumeiras das escravas revelam uma relativa autonomia para levar sua vida pessoal em seu escasso tempo livre. No entanto, Adèle apresenta o fato de essas mulheres saírem de casa desacompanhadas como imoralidade e até mesmo prostituição, reproduzindo os padrões vitorianos de moralidade. Para as escravas, porém, isso podia ser tanto uma possibilidade de ganhar dinheiro através da negociação de sua sexualidade quanto um meio de levar sua vida pessoal fora do controle de um senhor (Chalhoub, 2011). Adèle entende a força de trabalho como o corpo do escravo em si, e considera toda ação executada por eles, em qualquer aspecto de sua vida, como trabalho - ironicamente, o mesmo entendimento que os donos de escravos brasileiros tinham.

As mulheres escravizadas aparecem como fonte de imoralidade nas memórias de Adèle e nos relatos de muitos outros viajantes do período. No 
entanto, a narrativa de Adèle é inovadora ao enfatizar que essas mesmas mulheres eram vítimas da escravidão. Na verdade, há uma tensão em seu discurso. Como outros abolicionistas, ${ }^{13}$ ela despreza a degeneração dos negros, mas defende vigorosamente ideias antiescravistas. De acordo com seu relato, cenas de escravidão foram uma grande fonte de pesar para ela em seus primeiros anos no Brasil. Ela condena o que chama de ultrajante venda pública de seres humanos nos mercado de escravos do Rio. Enfatizando sua posição de esposa e mãe, ela denuncia o "comércio de carne humana", especialmente no tocante à separação de famílias e à venda de mulheres jovens para prestar serviços sexuais a seus senhores:

A cada instante, minha alma revoltava-se ou sangrava, quando eu passava diante de um daqueles leilóes em que pobres negros, em cima de uma mesa, eram leiloados e examinados nos dentes e nas pernas como cavalos ou mulas; quando via o lance ser coberto e uma jovem negra ser entregue ao fazendeiro que a reservava a seu serviço íntimo, enquanto seu negrinho era algumas vezes vendido a um outro senhor. Diante de todas essas cenas de barbárie, meu coração indignava-se, cóleras generosas inflamavam-se em mim, e eu era obrigada a conter-me para não gritar a todos aqueles homens que faziam comércio de carne humana: "carrascos". (Toussaint-Samson, 2003, p.97-98)

Adèle denuncia uma prática profundamente arraigada de donos de escravos: o aumento de sua propriedade de escravos mediante a violação sexual de escravas. No texto de Toussaint-Samson, o conceito de trabalho assume um significado mais amplo e abrange a exploração sexual das escravas que eram coagidas pela vontade de seu senhor. $\mathrm{O}$ que muitos brasileiros viam como normal e muitos viajantes homens sequer mencionavam, Adèle condenava radicalmente.

No final dos anos 1870, quando Toussaint-Samson publicou suas memórias, A cabana do Pai Tomás já era um clássico. O tema da separação familiar, especialmente de mãe e filho, e a violação sexual de mulheres jovens era uma imagem vigorosa frequentemente usada nos movimentos antiescravistas (Midgley, 1992). Uma parisiense no Brasil recorre a essa consagrada retórica antiescravista de gênero. A essa altura, os movimentos antiescravistas estavam consolidados em virtualmente todas as partes do mundo do Atlântico.

Ao revelar a realidade brasileira para leitores europeus, Adèle também exibe seu conhecimento sobre o Brasil. Em seu relato, a escravidão é um divisor de águas que separa a civilização na Europa do atraso no Brasil. Ao fazê-lo, 
Adèle vê os escravos por duas óticas ao mesmo tempo: eles são uma raça degenerada, mas também vítimas de um sistema cruel. Ela discute a escravidão para destacar a importância do trabalho livre de estilo europeu, criticando, deste modo, a noção brasileira de trabalho como uma atividade vergonhosa.

\section{CONSIDERAÇÕES FINAIS}

Nesse artigo, expus as ideias de duas escritoras, a francesa Adèle Toussaint-Samson e a brasileira Nísia Floresta. Apesar das diferenças entre suas obras literárias, elas compartilhavam pensamentos semelhantes sobre o papel da mulher na sociedade e os prejuízos da escravidão para o desenvolvimento da nação brasileira. Focando o Brasil nos anos 1850, elas reproduziram estereótipos similares sobre os brasileiros e seus costumes, que circularam através do tempo e do espaço. Também exploraram novos aspectos e revelaram realidades escondidas, especialmente no que diz respeito às mulheres livres e escravizadas. Suas obras nos mostram como seus pensamentos foram moldados por seu deslocamento espacial e pela circulação transnacional de ideias e imagens em diversos lugares do Atlântico. Ao contrário de muitos relatos de viagem que focavam a massa de homens africanos que dominava as ruas do Brasil, Nísia e Adèle entraram na vida doméstica para denunciar os sustentáculos da escravidão. Em vista disso, sua principal contribuição foi divulgar em ambos os lados do Atlântico um lado oculto da vida feminina e do trabalho escravo, que era negligenciado nas sociedades de meados do século XIX no mundo todo.

\section{REFERÊNCIAS}

ANAGOL, Padma. The Emergence of Feminism in India: 1850-1920. Cardiff University, UK: Ashgate, 2006.

CÂMARA, Adauto. História de Nísia Floresta. 2.ed. Rio de Janeiro: Irmãos Pongetti, 1941.

CANELAS, Letícia. Franceses "quarante-huitards" no Império dos Trópicos (18481862). 2007. Dissertação (Mestrado em História Social) - IFCH, Unicamp. Campinas, 2007.

CENSUS of Rio de Janeiro in 1849. Intr. Thomas Hollow. Disponível em: www.brnuede.com/bhds/bhd50/thrj.pdf; Acesso em: 28 out. 2013.

CHALHOUB, Sidney. Machado historiador. São Paulo: Companhia das Letras, 2003. 
CHALHOUB, Sidney. The Precariousness of Freedom in a Slave Society (Brazil in the Nineteenth Century). IRSH, p.1-35, 2011.

COWLING, Camillia. Women and the Abolition of Slavery in Havana and Rio de Janeiro. Social History, v.26, n.3, p.294-311, 2011.

DUARTE, Constância Lima. Nísia Floresta: vida e obra. 2.ed. Natal: Ed. UFRN, 2008.

FLORESTA, Nísia. Opúsculo humanitário. São Paulo: Cortez; Natal: Fundação José Augusto, 1989.

HALL, Michael; STOLCKE, Verena. The Introduction of Free Labor on São Paulo Coffee Plantations. Journal of Peasant Studies, v.10, n.3, jan.-abr., s.d.

KARASCH, Mary. Slave Life in Rio de Janeiro: 1808-1850. Princeton: Princeton University Press, 1987.

LÚCIO, Sônia Valéria. Uma viajante brasileira na Italia do risorgimento: tradução comentada do livro Trois Ans En Italie Suivis d'un Voyage en Grece (v.I, 1864; v.II, s.d.) de Nisia Floresta Brasileira Augusta. Tese (Doutorado em História e Teoria Literária) - IEL, Unicamp. Campinas, 2002.

McCLINTOCK, Anne. Couro imperial: raça, gênero e sexualidade no embate colonial. Trad. Plínio Detzen. Campinas: Ed. Unicamp, 2010.

MIDGLEY, Clare. Women Against Slavery: The British Campaigns, 1780-1870. London: Routledge, 1992.

SIMIONI, Ana Paula. Profissão artista: pintoras e escultoras acadêmicas brasileiras. São Paulo: Edusp; Fapesp, 2008.

STOWE, Harriet. Uncle Tom's Cabin. Oxford \& New York: Oxford University Press, 2007.

TOUSSAINT-SAMSON, Adèle. Uma parisiense no Brasil. Trad. Maria Lúcia Machado. Rio de Janeiro: Capivara, 2003.

VALENZE, Deborah. The First Industrial Woman. Oxford: Oxford University Press, 1995.

VAN DER LINDEN, Marcel. The Old, the New and the Global. African Studies, v.66, n.2-3, p.169-180, 2007.

WASHIGNTON, Margaret. From Motives of Delicacy: Sexuality and Morality in the Narratives of Sojourner Truth and Harriet Jacobs. The Journal of African American History, v.92, n.1, p.57-73, 2007.

WILDENTHAL, Lora. German Women for Empire: 1884-1945. Durham and London: Duke University Press, 2001.

\section{NOTAS}

${ }^{1}$ Esta pesquisa foi financiada pelo CNPq e pela Capes. Uma primeira versão do artigo foi apresentada na Escola de Verão da Unicamp em dezembro de 2013. Também agradeço à dra. Lora Wildenthal por seus comentários sobre o texto. 
${ }^{2}$ Nísia Floresta é um pseudônimo. Cf. CÂMARA, 1941.

${ }^{3}$ A imprensa da época reproduzia relatos de viagens de muitas partes do mundo. Por exemplo: Nouvelles de la science. Courrier du Brésil, Rio de Janeiro, 9 jan. 1859. Disponível em: http://memoria.bn.br/DocReader/docreader.aspx?bib=709719\&pesq=; Acesso em: 3 fev. 2013.

${ }^{4} \mathrm{O}$ ano era 1877. Cf. TOUSSAINT-SAMSON, 2003.

${ }^{5}$ A versão em inglês é A Parisien in Brazil e a original é Une parisienne au Brésil.

${ }^{6}$ Mulheres alemãs entraram no espaço público ao ir para a Namíbia e outros lugares da África para construir um império alemão lá. Cf. WILDENTHAL, 2001.

7 "Opúsculo" é sinônimo de "folheto" em português. Cf. verbete: opúsculo. In: HOUAISS, Antonio. Dicionário Antônio Houaiss da língua portuguesa. 2009, versão eletrônica.

${ }^{8}$ A série de matérias foi publicada entre 21 de abril e 24 de maio de 1853 no jornal Diário do Rio de Janeiro. Disponível em: http://memoria.bn.br/DocReader/docreader. aspx?bib=094170_01\&pasta=ano\%20185\&pesq=; Acesso em: 10 set. 2013.

${ }^{9}$ O pseudônimo é “B. A.”. Cf. FLORESTA, 1989.

${ }^{10}$ Diário do Rio de Janeiro, 1853. Disponível em: http://memoria.bn.br/DocReader/docreader.aspx?bib=094170_01\&pasta=ano\%20185\&pesq; Acesso em: 19 dez. 2012.

${ }^{11}$ Diário do Rio de Janeiro, 10 jan. 1853, p.4. Disponível em: http://memoria.bn.br/DocReader/docreader.aspx?bib=094170_01\&pasta=ano\%20185\&pesq; Acesso em: 10 ago. 2013.

${ }^{12}$ B. Augusta, Passeio ao aqueduto da Carioca. Variedades. O Brasil Illustrado. Essa série de artigos foi publicada originalmente em 15 de julho de 1855.

${ }^{13}$ Margaret Washington menciona o mesmo tipo de tensão na figura de Harriet Stowe em WASHIGNTON, 2007.

Artigo recebido em 7 de julho de 2014. Aprovado em 15 de outubro de 2014. 